\title{
NMDA Receptor Upregulation: Molecular Studies in Cultured Mouse Cortical Neurons after Chronic Antagonist Exposure
}

\author{
Paolo Follesa and Maharaj K. Ticku \\ Department of Pharmacology, The University of Texas Health Science Center, San Antonio, Texas 78284-7764
}

We examined the possibility of changes in gene expression of the NMDA receptor subunits after chronic antagonist treatment. Exposure of neurons to the NMDA antagonist $\mathrm{D}(-)-2-$ amino-5-phosphonopentanoic acid (AP-5) produced an increase in the levels of the R2B mRNA subunit. Concomitant exposure of neurons to AP-5 and NMDA reversed the upregulation. Chronic AP-5 treatment increased the R1 polypeptide, whereas no change was observed in the levels of mRNA encoding the R1 subunit. A more pronounced increase was ob- served in the R2A/B polypeptides. These data demonstrate that chronic treatment with NMDA antagonists selectively upregulates the NMDA receptor mRNAs and polypeptides. Furthermore, antagonist treatment produced a differential regulation of the R1, R2A, and R2B subunits in cortical neurons.

Key words: excitatory amino acids; NMDA receptor antagonist; mRNA subunit; immunoblot; upregulation; neuronal cell culture
The NMDA receptor (NMDAR), a subtype of glutamate receptors, is an oligomeric ligand-gated ion channel complex formed by the assembly of different subunits (Monyer et al., 1992). This receptor contains distinct recognition sites for endogenous and exogenous ligands, such as glutamate, glycine, $\mathrm{Mg}^{2+}, 7 \mathrm{n}^{2+}$, polyamines, and open-channel blockers such as MK-801 (Mayer and Westbrook, 1987; Collingridge and Lester, 1989; Watkins et al., 1990). Recent studies have demonstrated that the various NMDAR subunits may be subjected to differential regulation during development and by various ligands that modulate this receptor complex (Pujic et al., 1993; Riva et al., 1994; Sheng et al., 1994; Watanabe et al., 1994; Zhong et al., 1994; Follesa and Ticku, 1995). The functional properties of the NMDAR can be modulated by the presence of different NMDAR subunit types (Anantharam et al., 1992; Monyer et al., 1992). The NMDARs are thought to be involved in processes such as memory and learning, neuronal developmental plasticity, epileptogenesis, and in some forms of acute and chronic neuropathologies (Mayer and Westbrook, 1987; Choi, 1988; Collingridge and Lester, 1989). NMDAR antagonists can protect against excitotoxicity in vivo (McDonald et al., 1990) and in vitro (Choi, 1988; Goldberg et al., 1988). Based on these lines of evidence, the NMDAR antagonists could be useful therapeutic agents in the treatment of ischemic brain injury and certain neurological dysfunctions, such as epilepsy and neuronal degeneration, which may involve excessive glutamatergic transmission. (Choi, 1988; Albers et al., 1989; Muir and Lees, 1995).

One of the unwanted effects of chronic treatment with drugs, including receptor antagonists, is the development of pharmacodynamic tolerance (Aarons et al., 1980; Jenner and Marsden, 1983). The molecular mechanism(s) underlying this phenomenon have yet to be elucidated. There is evidence that treatment with the NMDAR

\footnotetext{
Received Oct. 10, 1995; revised Jan. 10, 1996; accepted Jan. 17, 1996.

This work was supported in part by National Institutes of Health-National Institute on Alcohol Abuse and Alcoholism Grant AA10552. We thank Mrs. Sadie Phillips for excellent secretarial assistancc.

Correspondence should be addressed to Dr. M. K. Ticku, Department of Pharmacology, The University of Texas Health Science Center, 7703 Floyd Curl Drive, San Antonio, TX 78284-7764.

Copyright $(C) 1996$ Society for Neuroscience $0270-6474 / 96 / 162172-07 \$ 05.00 / 0$
}

antagonists, in vivo and in cell culture, leads to upregulation of the NMDA receptors, as measured by radioligand-binding studies (McDonald et al., 1990; Williams et al., 1992). I Iowever, it is not known whether an increase in binding corresponds to a real increase in the protein and mRNA expression, or whether other mechanisms are involved in this phenomenon. Furthermore, oligomeric receptors such as the NMDAR, composed by different subunits, are derived from different genes (Moriyoshi et al., 1991; Monyer et al., 1994); it is not known whether all the genes encoding the diverse subunits are equally or differentially regulated in response to a particular treatment.

The use of animals to study the effect of antagonists on the NMDAR is not always desirable. Primary neuronal cell cultures provide a useful model to study the pharmacology and the molecular phenomenon that may be related to the regulation of the NMDAR expression.

In the present study, we tested the hypotheses that the upregulation of the NMDAR complex observed after chronic antagonist exposure may be attributable to an increase in the mRNA and polypeptide expression of the different NMDAR subunits.

\section{MATERIALS AND METHODS}

cDNA preparation. The primer pairs (sequences published in Follesa and Ticku, 1995) were designed to include cDNA sequences with the lowest degrec of homology between the mRNA of the different mouse NMDA receptor subunits $R 2 A, R 2 B$, and $R 2 C$, as described previously for the rat (Follesa and Ticku, 1995) (assisted by Genetics Computer Group, program manual for the GCG package, version 7, Madison, WI). The mouse subunits are called $\epsilon_{1}, \epsilon_{2}$, and $\epsilon_{3}$, respectively, by Kutsuwada et al. (1992). For simplicity we use the rat nomenclature R1, R2A-C throughout the article. Extracted RNA (Chomczynski and Sacchi, 1987) from mouse brain was reverse-transcribed with SuperScript RT RNase $\mathrm{H}^{-}$Reverse Transcriptase (Life Technologies, Gaithersburg, MD) in presence of oligo-dT. The resulting cDNA was used for PCR (Veres et al., 1987). PCR was performed with Thermus aquaticus (Taq) DNA polymerase (Perkin-Elmer/Cetus, Norwalk, CT) in $100 \mu \mathrm{l}$ of standard buffer $(100 \mathrm{~mm}$ Tris-HCl, pH 8.3, $500 \mathrm{~mm} \mathrm{KCl}, 15 \mathrm{~mm} \mathrm{MgCl}_{2}, 0.01 \%$ (w/v) gelatin), containing the cDNA and $1 \mu \mathrm{M}$ of primers (specific for each individual mRNA encoding the different NMDA receptor subunits), and $200 \mu \mathrm{M}$ each deoxynucleoside triphosphate, $2.5 \mathrm{U} / 100 \mu \mathrm{l}$ AmpliTaq DNA Polymerase. Thirty amplification cycles in a SingleBlock System apparatus 
(ERICOMP, San Diego, CA) were used. Each cycle consisted of $94^{\circ} \mathrm{C} / 45$ scc, $60^{\circ} \mathrm{C} / 1 \mathrm{~min}$, and $72^{\circ} \mathrm{C} / 1 \mathrm{~min}$ (with a final extension of $15 \mathrm{~min}$ ) (Bovolin et al., 1992; Ishii et al., 1993). PCR products were separated on $1.8 \%$ low-melting agarose gel by electrophoresis. DNA bands visualized by ethidium bromide were cut out and purified. DNA fragments were inserted in pAMP 1 cloning vector (Life Technologies) and used to transform NM522 Escherichia coli. Plasmid was then purified and cDNA was sequenced. Sequencing was performed using a Sequenase DNA sequencing kit (USB, Cleveland, $\mathrm{OH}$ ). The nucleotide sequences were compared with the published sequence demonstrating $100 \%$ homology (Kutsuwada et al., 1992). Each cDNA was then used as a template to generate a cRNA probe, which was labeled with $\left[\alpha-{ }^{32} \mathrm{P}\right]$ cytidine triphosphate (CTP) to perform the RNase protection assay.

Probe preparation. Plasmids pFPR2AM, pFPR2BM, and pFPR2CM containing the cDNA fragment for the R2A, R2B, and R2C NMDA receptor subunits, respectively, were linearized with $E c o$ RI, and SP6 RNA polymerase was used to generate each $\left[\alpha-{ }^{32} \mathrm{P}\right] \mathrm{CTP}$-labeled cRNA. The R2A cRNA was 662 bases long and included 570 bases of the R2A cDNA and 92 bases of the polylinker region of the pAMP 1 cloning vector $(570+92)$. The R2B cRNA was 530 bases long $(438+92)$, and the R2C was 404 bases long $(312+92)$. The rat NMDA receptor $R 1$ subunit clone $\mathrm{P} 15$ was provided in the pSP64(poly A)-N vector (Promega, Madison, WI) (a gift from Dr. Steven N. Trcistman, University of Massachusetts Medical Center, Worcester, MA). The R1 cDNA clone was digested with HindIII and XhoI, and the cDNA fragment ( 1230 bp of the $5^{\prime}$ region) was subcloned into pGEM $7 Z \mathrm{f}(-)$ (Promega). An EcoRI-lincarized plasmid was used as a template, using the T7 RNA polymerase to generate a $\left[\alpha^{32} \mathrm{P}\right] \mathrm{CTP}$-labeled 189 -base-long probe that includes 152 bases of R1 CDNA and 37 bases of the pGEM polylinker region. This probe does not discriminate between the different splicing variants of the $R 1$ subunit (Anantharam et al., 1992), and the region selected (152 bp) has 100\% homology with the mouse mRNA. Plasmid p15GI (Follesa and Mocchetti, 1993), a derivative of plasmid p1B15, contains a partial sequence of the rat gene for cyclophilin (Milner and Sutcliffe, 1983; Danielson et al., 1988), a constitutive protein. The EcoRI linearized plasmid was used as a template to generate a cRNA composed of 294 bases, complementary to the cyclophilin RNA and seven bases of the polylinker region of pGEM 1 (Promega).

Cell culture. Time-pregnant mice (strain $\mathrm{C} 57 \mathrm{BL} / 6$ ) were purchased from Harlan (Indianapolis, IN). All animals were used in accordance with institutional guidelines, and procedures were approved by an animal welfare committee. Cerebral hemispheres were dissected from 14- to 15-d-old fetuses, and cells were dissociated by trituration using a Pasteur pipette as described previously (Hu et al., 1996). Dissociated cells were counted under a microscope using a hemocytometer, and the trypan blue stain method was used to determine the number of viable cells. Cells were resuspended in the culture medium to have $2 \times 10^{6} \mathrm{cells} / \mathrm{ml}$, and $12 \mathrm{ml}$ of this cell suspension were used for each poly-L-lysine-coated $75 \mathrm{~cm}^{2}$ plastic flasks. The cells were grown in Minimum Essential Medium (MEM) containing $33.3 \mathrm{~mm}$ glucose, $26.2 \mathrm{mM} \mathrm{NaHCO}_{3}, 100 \mu \mathrm{M} \mathrm{L}$-glutamine, $10 \%$ fetal bovine serum (FBS), and 10\% horse serum (MEM 10/10) in an incubator with $95 \% \mathrm{O}_{2} / 5 \% \mathrm{CO}_{2}$ at $37^{\circ} \mathrm{C}$.

The concentration of L-glutamine used in the present study was $100 \mu \mathrm{M}$ as opposed to $2 \mathrm{~mm}$ used in a previous study (Hu and Ticku, 1995). This variation in experimental conditions is justified by the fact that a concentration of $2 \mathrm{~mm}$ glutamine produces high concentrations of glutamate (Hamilton, 1945). In one pilot experiment, the concentration of glutamate was measured $(495 \pm 35 \mu \mathrm{M} ; n=3)$ in the $2 \mathrm{mM}$ L-glutaminecontaining media using a glutamine-glutamate determination kit (Sigma, St. Louis, MO). This high concentration of glutamate prevented the $\mathrm{D}(-)$-2-amino-5-phosphonopentanoic acid (AP-5)-induced upregulation of the NMDARs (see Results).

Because the expression of the NMDAR subunit mRNA depends on the concentration of FBS in the media (Zhong et al., 1994; Follesa and Ticku, unpublished observations), the media was substituted with MEM containing 5\% FBS plus 5\% horse serum (MEM/10) on the second day in culture. In addition, on the second day in culture a mixture of 5-fluoro$2^{\prime}$-deoxyuridine and uridine at a final concentration of $10 \mu \mathrm{g} / \mathrm{ml}$ was added to the media to inhibit cell proliferation (Godfrey et al., 1975).

Chronic exposure with the NMDAR antagonist and/or other drugs was initiated on the third day and lasted for $5 \mathrm{~d}$ or as indicated. MEM/10 containing freshly prepared drugs was replaced every $24 \mathrm{hr}$. All drugs were dissolved in MEM except CNQX, which was dissolved in dimethyl sulfoxide (DMSO). On the seventh day in culture, cells were harvested for either total RNA (Chomczynski and Sacchi, 1987) or protein extraction (Wenthold et al., 1994).

RNase protection assay. The RNase protection assay was performed as described previously (Follesa and Mocchetti, 1993; Follesa and Ticku, 1995). Total RNA was extracted (Chomczynski and Sacchi, 1987) from each flask and quantified by measuring absorbance at $260 \mathrm{~nm}$. Briefly, 25 $\mu \mathrm{g}$ of total RNA were dissolved in $20 \mu \mathrm{l}$ of hybridization solution containing $150,000 \mathrm{cpm}$ of each ${ }^{32} \mathrm{P}$-labeled NMDAR cRNA probe (specific activity $\sim 6-7 \times 10^{7} \mathrm{cpm} / \mu \mathrm{g}$ RNA) and $15,000 \mathrm{cpm}$ of ${ }^{32} \mathrm{P}$-labeled cyclophilin cRNA (specific activity $\sim 1 \times 10^{6} \mathrm{cpm} / \mu \mathrm{g}$ RNA). The samples were then incubated at $50^{\circ} \mathrm{C}$ overnight to allow hybridization of the cRNA probe to the RNA. The next day digestion was performed at $37^{\circ} \mathrm{C}$ for 30 min using an RNase solution containing a final concentration of 0.5 units/ml RNase A III (Sigma) and 100 units/mI RNase T1 (Sigma). The RNA-RNA hybrids were separated on a $5 \%$ polyacrylamide/urea sequencing gel. The gel was dried, and the mRNA-protected fragments were visualized by autoradiography on $\mathrm{x}$-ray film (KODAK X-OMAT AR, Kodak, Rochester, NY) using an intensifying screen (KODAK X-OMATIC, Kodak). Films were exposed overnight at $-80^{\circ} \mathrm{C}$. Films were used for illustration proposes only (see Fig. 2) and not for quantification. Quantification was performed as described in Calculation and Statistic Analysis. (see below).

Electrophoresis and immunoblot of NMDAR subunits. Cells were washed 2 times with PBS and harvested in $50 \mathrm{~mm}$ Tris $\mathrm{HCl}, \mathrm{pH} 7.0$ (Wenthold et al., 1994). The harvested cells were pelleted, homogenized in the same buffer with a polytron, and centrifuged at $55,000 \times$ $g$ for $20 \mathrm{~min}$. Pellets were homogenized in $3 \mathrm{ml}$ of Tris $\mathrm{HCl}$ and frozen at $-20^{\circ} \mathrm{C}$ for later use (Wenthold et al., 1994). The amount of protein was determined using BCA Protein Assay Reagent (Pierce, Rockford, IL). Indicated amount of proteins was separated by $8.5 \%$ sodium docecyl sulfate-polyacrylamide gel electrophoresis (SDS-PAGE) according to the method of Laemmli (1970). The two gels were run in parallel; one was stained with the Coomassie blue, the other was used for the transfer. Proteins were transferred on a nitrocellulose membranc and blocked with TBS containing $5 \%$ milk powder and $0.05 \%$ Tween 20 (TBS-T). The blot was then incubated with the rat polyclonal antibody affinity-purified for NMDAR R1 (AB1516, selective for all 4 splice variants, Chemicon, Temecula, CA) or R2A and R2B (AB1548, recognizes both $\mathrm{R} 2 \mathrm{~A}$ and $\mathrm{R} 2 \mathrm{~B}$ subunits equally, Chemicon) at a concentration of $0.5 \mu \mathrm{g} / \mathrm{ml}$. The blot was washed several times with TBS-T and then incubated with the secondary antibody, peroxidaseconjugated anti-rabbit IgG (dilution 1:10,000), and specific bands were visualized on a film (KODAK X-OMAT LS, Kodak) using the electrogenerated chemiluminescence detection system (Amersham, Arlington Heights, IL).

Calculation and statistic analysis. The content of NMDA receptor subunits mRNA and cyclophilin mRNA was evaluated by measuring the radioactivity for each band on the gel using a Betascope 603 Blot Analyzer (Betagen, Mountain View, CA) (Follesa and Ticku, 1995). The

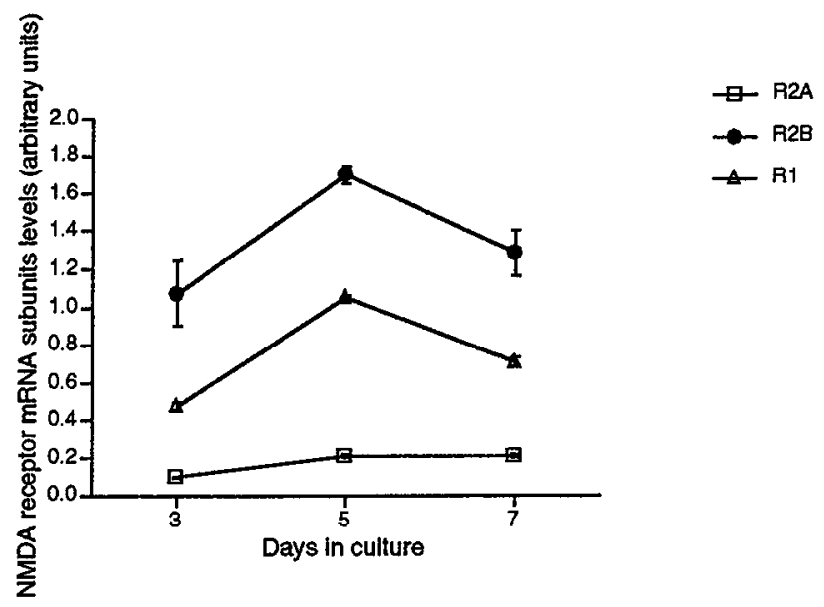

Figure 1. Relative mRNA levels of the three different subunits of the NMDAR complex at days 3,5, and 7 in cultures in untreated neurons. Values are expressed in arbitrary units (ratio between counts per minute) and are the mean \pm SEM of three experiments. 


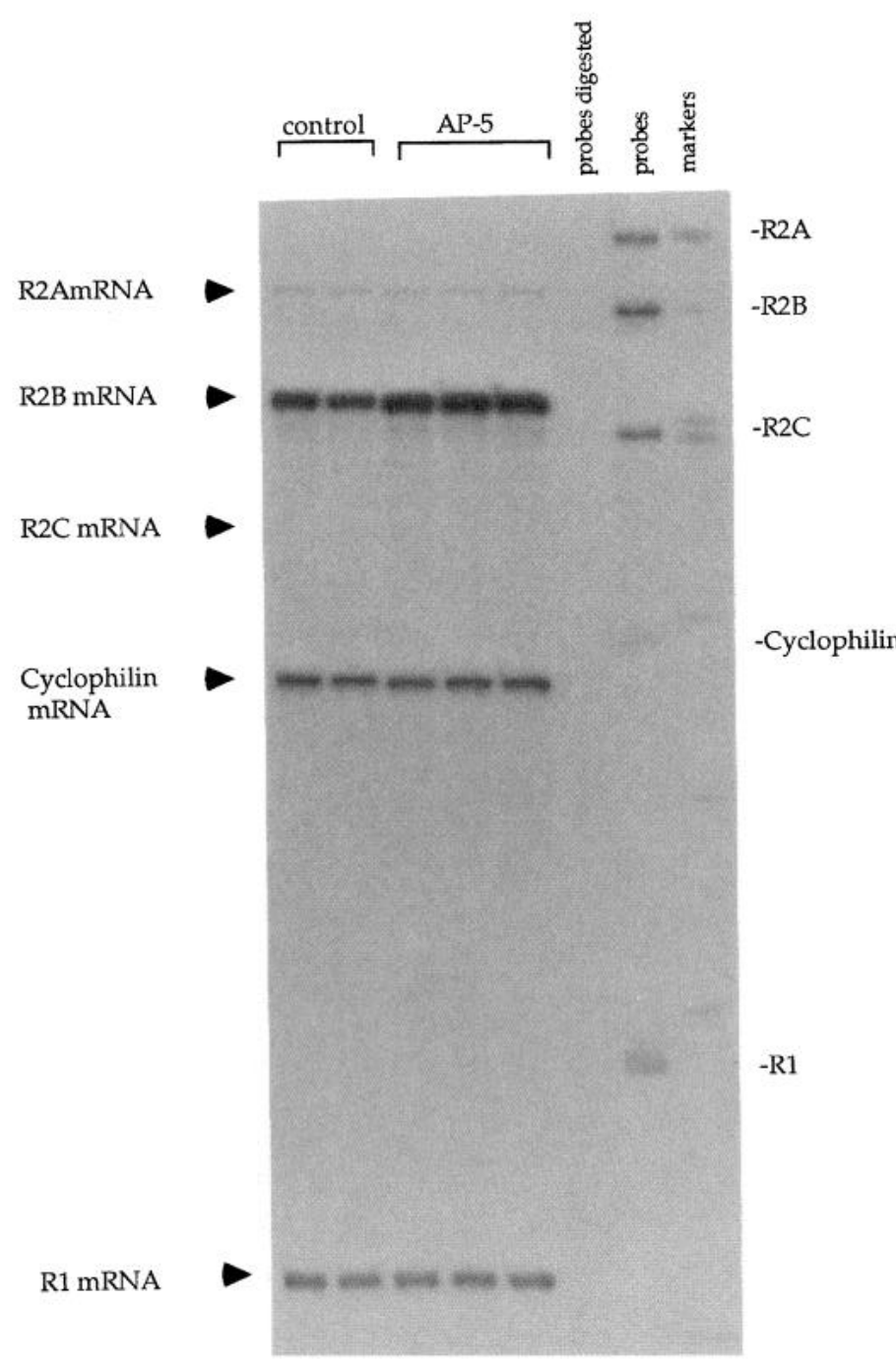

Figure 2. NMDA receptor subunit mRNA detection by RNase protection assay. Autoradiograph showing positions of the NMDAR subunit mRNAs on a urea/polyacrylamide electrophoresis gel. Arrowheads indicate position of protected fragments (see Materials and Methods) of the NMDAR subunit mRNAs. Cells were treated with $A P-5(100 \mu \mathrm{M} ; 5$ d). The total RNA was extracted (as described in Materials and Methods) from mouse cortical neurons $8 \mathrm{~d}$ in culture. On each lane, $25 \mu \mathrm{g}$ of total RNA from individual flasks were loaded. Note that the NR2C mRNA is absent. Chronic AP-5 treatment produced upregulation of the R2B subunit mRNA and no significant changes in the levels of R1 and R2A subunit mRNA. The values are summarized in Table 1. Cyclophilin was used as a control to decrease the experimental error attributable to differences in loading and concentration of RNA on each lane. Marker size (in base pairs): $720 ; 553 ; 500 ; 427 ; 417+413 ; 311 ; 249 ; 200 ; 151$.

values were normalized by dividing the number of counts per minute of each protected fragment band of the different NMDA receptor subunits by the number of counts per minute of each protected fragment band of the cyclophilin, and expressing the amount of mRNA in arbitrary units (ratio between counts per minute).

For the immunoblot experiments, the relative changes in expression of polypeptides were calculated estimating the intensity of the band with National Institutes of Health IMAGE system. The data were normalized to the amount of proteins loaded in each lane in the Coomassie bluestained gel that was run in parallel by measuring both the major band of $\sim 58 \mathrm{kDa}$ (see Fig. $5 c$ ) and the intensity of the whole lane. We performed pilot studies in which different amounts of protein $(10-60 \mu \mathrm{g})$ were loaded on the gel with the antibodies used in the present study, and we observed that the intensity of the bands was in the linear range for both
Table 1. Increase in R2B subunit mRNA after chronic NMDAR antagonist exposure

mRNA levels (\% increase or decrease with respect to control)

\begin{tabular}{lcrr}
\cline { 2 - 4 } Treatment & R2A & \multicolumn{1}{c}{ R2B } & \multicolumn{1}{c}{ R1 } \\
\hline AP-5 $(100 \mu \mathrm{M})$ & $1 \pm 2$ & $45 \pm 3^{*}$ & $-4 \pm 5$ \\
AP-5 $(100 \mu \mathrm{M})+$ NMDA $(1 \mathrm{mM})$ & $1 \pm 6$ & $5 \pm 3$ & $7 \pm 6$ \\
MK-801 $(1 \mu \mathrm{M})$ & $6 \pm 6$ & $40 \pm 4^{*}$ & $-11 \pm 6$ \\
CNQX $(10 \mu \mathrm{M})$ & $2 \pm 2$ & $2 \pm 4$ & $0 \pm 3$
\end{tabular}

Cells were treated for $5 \mathrm{~d}$, as described in Materials and Methods. AP-5-mediated increase in R2B mRNA levels did not occur in the presence of NMDA (1 mM). The noncompetitive antagonist MK-801 $(1 \mu \mathrm{M})$ also produced upregulation of the R2B mRNA subunit similar to AP-5. The non-NMDAR antagonist CNQX $(10 \mu \mathrm{M})$ did not alter any of the NMDAR mRNA subunits. Values are expressed as percentage of control and are the mean \pm SEM of three to six experiments.

${ }^{*} p<0.01 ;$ compared with the control group (ANOVA and Sheffe's test).

control and AP-5-treated standard curves. For subsequent experiments, we used $20-30 \mu \mathrm{g}$ of protein. For both mRNA and polypeptide, the data were expressed as percentage of increase or decrease from the control \pm SEM. The statistical analysis was performed by ANOVA and Sheffe's test.

\section{RESULTS}

\section{Expression of NMDAR subunit mRNA in cultured mouse cortical neurons}

Figure 1 shows the relative levels of mRNA for the three different subunits of the NMDAR complex at days 3,5, and 7 in cultured cortical neurons that exhibited the following rank order: R2B > $\mathrm{R} 1>\mathrm{R} 2 \mathrm{~A}$. The R2C subunit mRNA was not expressed in this cell culture preparation (Fig. 2).

\section{Prolonged AP-5 exposure selectively upregulates NMDAR R2B mRNA subunit}

Our initial experiments were performed using the $2 \mathrm{~mm}$ glutamine-containing medium. Under these conditions, exposure

\section{Table 2. Increase in NMDAR subunit polypeptides after chronic NMDAR antagonist exposure}

Polypeptide levels (\% increase or decrease with respect to control)

\begin{tabular}{lcc}
\cline { 2 - 3 } Treatment & R2A/B & R1 \\
\hline AP-5 $(100 \mu \mathrm{M})$ & $567 \pm 70^{* *}$ & $62 \pm 11^{*}$ \\
MK-801 $(1 \mu \mathrm{M})$ & $496 \pm 41^{*}$ & $72 \pm 31^{*}$ \\
CNQX $(10 \mu \mathrm{M})$ & $59 \pm 37$ & $-5 \pm 5$ \\
AP-5 $(100 \mu \mathrm{M})+$ NMDA $(100 \mu \mathrm{M})$ & $478 \pm 50^{*}$ & $44 \pm 3^{*}$ \\
NMDA $(100 \mu \mathrm{M})$ & $10 \pm 2$ & $2 \pm 4$ \\
AP-5 $(100 \mu \mathrm{M})+$ NMDA $(1 \mathrm{mM})$ & $60 \pm 59$ & $5 \pm 4$ \\
NMDA $(1 \mathrm{mM})$ & $-16 \pm 11$ & $-7 \pm 23$
\end{tabular}

The upregulation of the NMDAR subunit polypeptides was reversed by concomitant exposure of AP-5 (100 $\mu \mathrm{M})$ and NMDA (1 mM). Chronic treatment with nonNMDAR antagonist CNQX $(10 \mu \mathrm{M})$ did not alter any of the NMDAR polypeptide levels. Cells were treated for $5 \mathrm{~d}$ with the indicated drugs. Values were normalized as explained in Materials and Methods and are expressed as percentage of control, and are the mean \pm SEM of three to six experiments.

${ }^{*} p<0.05$, * $p<0.001$; compared with the control group (ANOVA and Sheffe's test). 


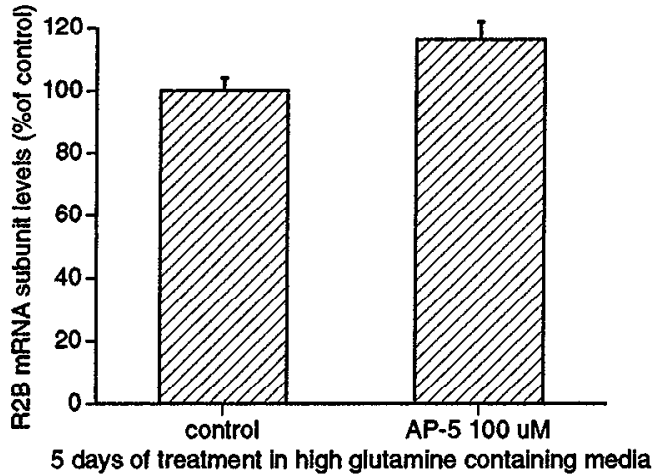

Figure 3. The upregulation of the R2B mRNA subunit of the NMDAR did not occur in cells treated for $5 \mathrm{~d}$ with AP-5 $(100 \mu \mathrm{M})$ in high glutamine ( $2 \mathrm{mM}$ )-containing media. Values are expressed as percentage of increase or decrease with respect to the control, and are the mean \pm SEM of six experiments.

of the cells to AP-5 (100 $\mu \mathrm{M} ; 5 \mathrm{~d})$ did not upregulate the R2B mRNA subunit (Fig. 3). All the subsequent experiments were performed using a concentration of $100 \mu \mathrm{M}$ glutamine as described in Materials and Methods. Under these conditions, exposure of the neurons to the competitive NMDAR antagonist AP-5

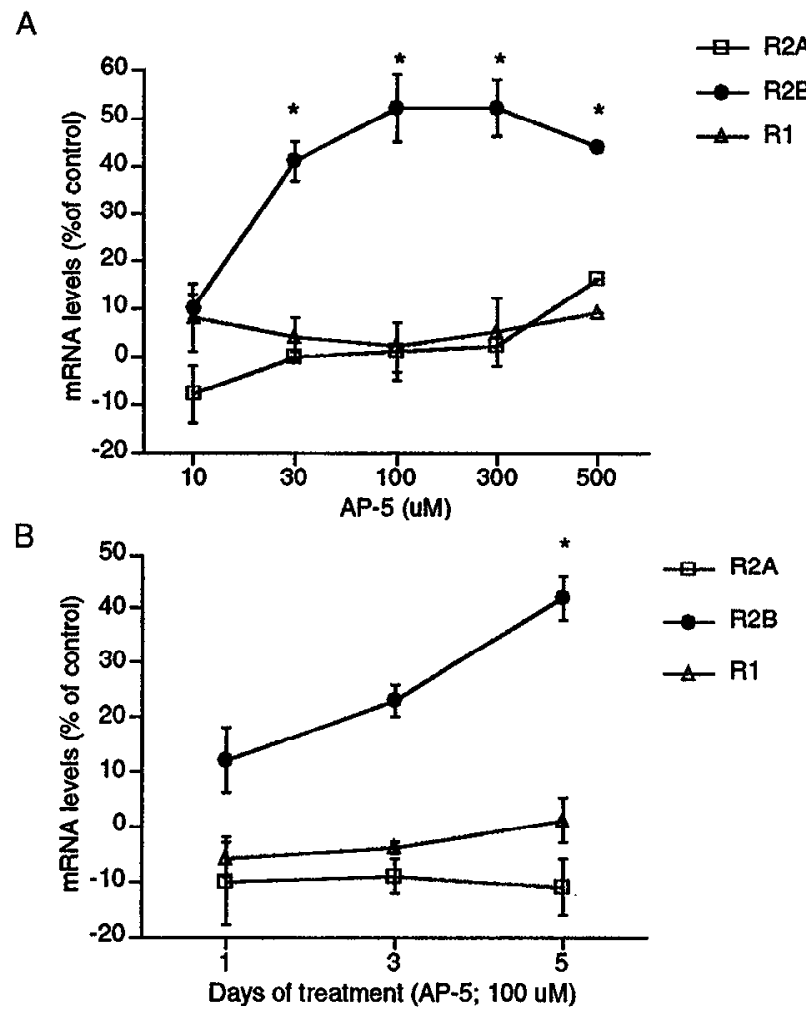

Figure 4. A, Concentration-dependent effect of AP-5 $(10-500 \mu \mathrm{M} ; 5 \mathrm{~d})$ on the NMDAR mRNA subunits in culturcd neurons. $B$, Time dependence of AP-5 $(100 \mu \mathrm{M})$ induced upregulation of the R2B mRNA subunit. The media containing fresh drugs was replaced every day. Cells were harvested at the indicated days in culture. Each group was compared with the respective control. Values are expressed as percentage of increase or decrease with respect to control, and are the mean \pm SEM of three experiments. ${ }^{*} p<0.01$; compared with the control group; ANOVA and Sheffe's test. for $5 \mathrm{~d}$ selectively increased the mRNA levels of the R2B subunit (45\%) without altering the levels of mRNA encoding for the R1 and R2A subunits (Fig. 2, Table 1). This effect was concentrationdependent (Fig. 4A). Using concentrations ranging from 10 to 500 $\mu \mathrm{M}$, we observed a maximum increase of mRNA encoding for the $\mathrm{R} 2 \mathrm{~B}$ subunit at $100 \mu \mathrm{M}(5 \mathrm{~d})$. The NMDAR R2B subunit mRNA upregulation was also time-dependent (Fig. 4B), and the peak increase was observed after $5 \mathrm{~d}$ exposure. Longer exposure (up to $7 \mathrm{~d}$ ) produced the same effect as $5 \mathrm{~d}$ exposure (data not shown), so for subsequent experiments we used a concentration of $100 \mu \mathrm{M}$ AP-5 for $5 \mathrm{~d}$. The observed upregulation was reversible, because $48 \mathrm{hr}$ removal of the antagonist returned the R2B subunit mRNA to the control levels (data not shown).

Concomitant exposure of AP-5 (100 $\mu \mathrm{M} ; 5 \mathrm{~d})$ and NMDA (1 $\mathrm{mM} ; 5 \mathrm{~d}$ ) was able to reverse the AP-5-mediated upregulation of the NMDAR (Table 1). Chronic exposure of the cortical neurons to the NMDA receptor open-channel blocker MK-801 ( $1 \mu \mathrm{M} ; 5 \mathrm{~d})$ also produced an increase $(40 \%)$ in the R2B mRNA subunit (Table 1). In contrast, chronic exposure $(10 \mu \mathrm{M} ; 5 \mathrm{~d})$ to the non-NMDAR antagonist 6-cyano-7-nitroquinoxaline-2,3-dione (CNQX) did not produce upregulation of any of the NMDAR mRNA subunits (Table 1).

\section{AP-5-mediated upregulation of the NMDAR polypeptides}

To further characterize the AP-5-mediated upregulation of the NMDAR complex, we wanted to verify whether an increase in mRNA expression corresponded to a concomitant increase in the NMDAR subunit polypeptide (using the concentration of $100 \mu \mathrm{M}$ for $5 \mathrm{~d}$ that gives the maximal response). We immunodetected the NMDAR polypeptide subunits using the AB1548 antibody [which recognized the $\mathrm{R} 2 \mathrm{~A} / \mathrm{B}$ subunit and gives a single band of $165 \mathrm{kDa}$ (Fig. 5a)] and the AB1516 antibody [which recognized the $R 1$ subunit and gives a single band of 116 $\mathrm{kDa}$ (Fig. $5 b$ )]. We found that $5 \mathrm{~d}$ exposure to the NMDAR antagonist AP-5 $(100 \mu \mathrm{M})$ produced a $60-70 \%$ increase in the levels of the R1 subunit polypeptide (Fig. 5, Table 2) without altering the mRNA levels of this subunit (Table 1). We also observed a fivefold increase in the levels of the R2 subunit polypeptides in the AP-5-treated cells compared with control cells. MK-801 (1 $\mu \mathrm{M} ; 5 \mathrm{~d})$ produced a similar effect as AP-5 (100 $\mu \mathrm{M} ; 5 \mathrm{~d})$ (Table 2), and the non-NMDAR antagonist CNQX $(10 \mu \mathrm{M} ; 5 \mathrm{~d})$ had no effect on the NMDAR expression (Fig. 5, Table 2). The effect of AP-5 was reversed by concomitant exposure of NMDA (1 mm; $5 \mathrm{~d}$ ) (Fig. 5, Table 2). Lower concentration of NMDA $(100 \mu \mathrm{M} ; 5 \mathrm{~d})$ did not block the AP-5-mediated increase in NMDAR polypeptide subunits (Table 2). Cells treated with NMDA (1 mM; $5 \mathrm{~d}$ ) alone did not show any morphological differences (dala not shown) or changes in the NMDAR polypeptide expression with respect to control cells (Table 2). These results are in agreement with the results obtained in the experiments in which high concentrations of glutamine and glutamate were present in the media (Fig. 3).

\section{DISCUSSION}

The use of NMDAR antagonists as potential therapeutic agents to diminish or ameliorate the progression of degenerative diseases or syndromes in which glutamatergic transmission may be involved has been proposed (Choi, 1988), and several NMDAR 


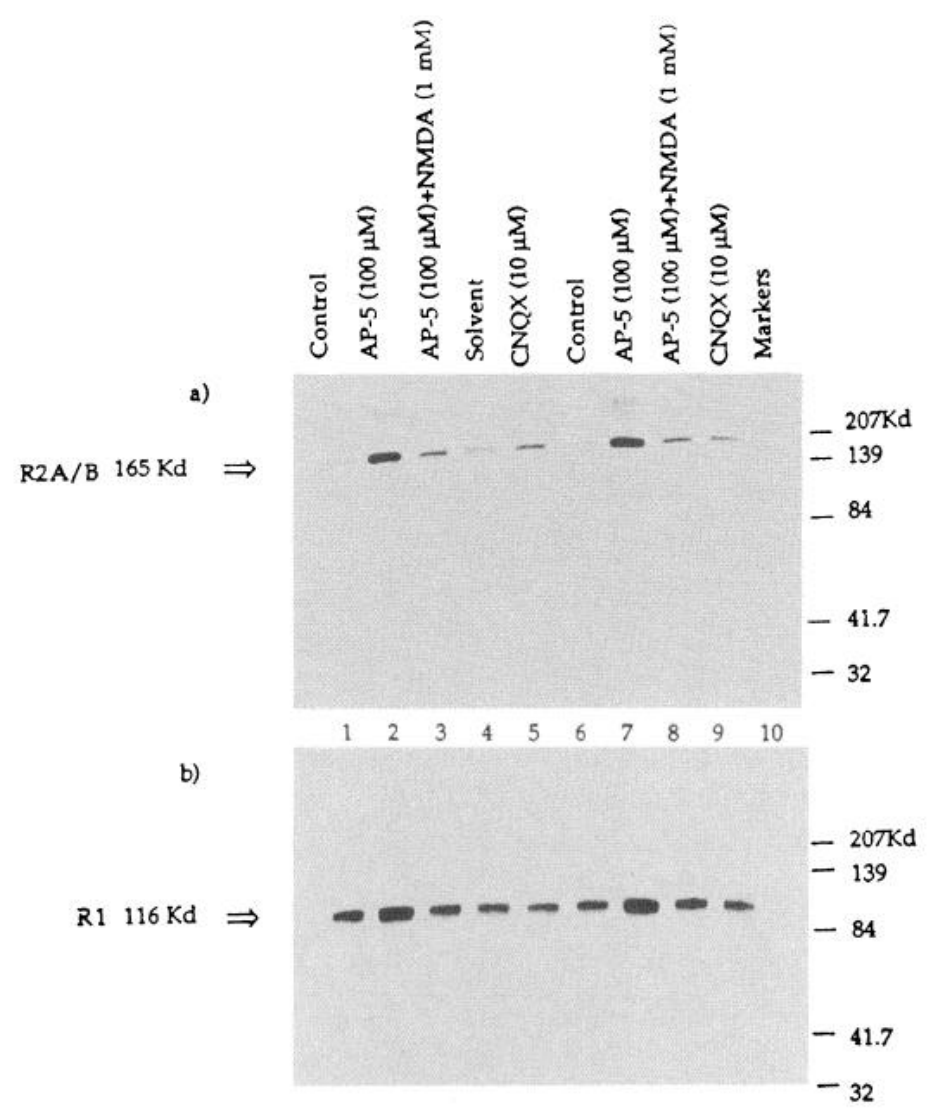

c)

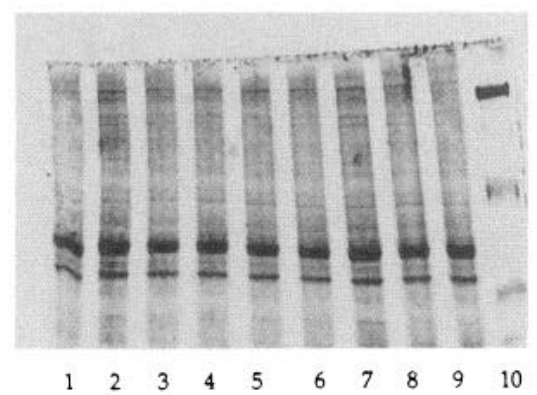

Figure 5. Representative SDS-PAGE and immunoblot analysis showing upregulation of both the R2A/B $(a)$ and R1 polypeptides $(b)$, and Coomassie blue staining of a gel ran in parallel $(c)$. Cells were treated with the indicated drugs for $5 \mathrm{~d}$. All drugs were dissolved in media except for $C N Q X$, which was dissolved in DMSO (Solvent) as explained in Materials and Methods. Proteins from each experimental group $(20 \mu \mathrm{g})$ were loaded in an $8.5 \%$ SDS-PAGE in duplicate (except for the solvent group) as follows: 1, 6 (Control); 2, 7 (AP-5); 3, $8(A P-5+N M D A) ; 4$ (Solvent); 5, 9 $(C N Q X) ; 10$ (Markers). Various treatments are indicated for each lane. Arrows indicate immunoreactive bands identified as R2A/B (165 kDa) $(R 2 A / B 165 \mathrm{Kd})$ and $\mathrm{R} 1(116 \mathrm{kDa})(\mathrm{RI} 116 \mathrm{Kd})$. The bars show the position of the prestained standard markers: myosin (207 kDa); $\beta$-galactosidase $(139 \mathrm{kDa})$; bovine serum albumin $(84 \mathrm{kDa})$; carbonic anhydrase (41.7 kDa); soybean trypsin inhibitor (32 kDa).

antagonists are currently in clinical trials (Muir and Lees, 1995). However, chronic treatment with receptor antagonists can lead to an increased density of receptors that may complicate the therapeutic efficacy of such drugs (Aarons et al., 1980; Jenner and Marsden, 1983; McDonald et al., 1990). It has been demonstrated that treatment with the NMDAR antagonists produces an upregulation of the NMDAR complex in vivo and in cortical cultures as measured by an increase in the $B_{\max }$ of NMDAR binding sites
(McDonald et al., 1990; Williams et al., 1992) and an increase in the receptor function (Hu and Ticku, unpublished observations).

In the present study, we examined the hypothesis that upregulation of the NMDAR complex observed after chronic antagonist treatment (Williams et al., 1992) may be attributable to an increase in gene expression of the different subunits composing the NMDARs. To examine this possibility, we measured the mRNA levels for each of the three NMDAR subunits present in the mouse cortical neurons in culture. In addition, using specific antibodies against the R1 and R2A/B polypeptides, we measured the protein levels after NMDAR antagonist treatment.

We found that the R1 subunit polypeptide levels were increased $60-70 \%$ after chronic NMDAR antagonist treatment, despite no apparent change in the mRNA levels for the same subunit. We also found that AP-5 treatment increased the R2B mRNA subunit by $\sim 45 \%$, whereas the mRNA levels for the other two subunits of the NMDAR (R1 and R2A) were not altered. The increase in the R2B mRNA levels was accompanied by a concomitant larger increase (fivefold) in the levels of the R2A/B polypeptides. These effects were blocked by concomitant exposure of AP-5 with NMDA, or in experiments in which high glutaminecontaining media were used, suggesting that the upregulation was mediated via NMDA receptors, most likely by blocking the tonic activation of the NMDARs. Under our experimental conditions, NMDA alone did not have any effect on the levels of NMDAR polypeptides and did not produce cell death. Because polypeptide levels were not altered, we did not measure the effect of NMDA on mRNA levels. However, it should be pointed out that, depending on the depolarizing conditions, NMDA can up- or downregulate the NMDARs (Bessho et al., 1994; Resink et al., 1995).

Taken together, our data suggest that the increase in the R1 polypeptide expression, but not in its mRNA, could be determined by a translational or post-translational regulation. It is worth mentioning that in PC12 cells the mRNA encoding the R1 subunit is transcribed, but the correspondent protein is not expressed, suggesting a post-transcriptional control for the expression of the R1 polypeptide (Sucher et al., 1993). The antagonist-mediated upregulation of the R2A/B subunits is attributable to an increase in their polypeptide levels because of an increase in transcription or mRNA stability and/or a decrease in mRNA turnover. This possibility exists at least for the R2B subunit, because we recently found that the R2A subunit polypeptide is virtually absent in the 7-d-old cultured neurons that were used in this study, and the expression of this protein increases later during maturation of these neurons in culture (Follesa, unpublished observations). Additional studies are needed to elucidate the potential mechanisms involved in this regulation.

There is no information available about the exact stoichiometry of the NMDAR complex. It has been suggested that the two classes of subunits need to be present in the same NMDAR complex to form functional receptors (Monyer et al., 1992). Histological and ultrastructural evidence indicates that the R1 and $\mathrm{R} 2 \mathrm{~A} / \mathrm{B}$ proteins are colocalized in many neuronal populations (Petralia et al., 1994) and in the same receptor (Sheng et al., 1994). Therefore, it is reasonable to assume that when we observed an increase in the number of NMDARs, both classes of subunits, i.e., R1, and R2, are increased. If so, it is feasible that the relatively small increase in the $\mathrm{R} 1$ subunit polypeptide observed in our study may account for the increase in the 
number of receptors, which is similar to the increase in $\left[{ }^{125}\right.$ I]MK-801 binding sites $(40-80 \%)$ (Williams et al., 1992; Follesa, unpublished observations). With respect to the R2 subunits, it is reasonable to assume that all the $\mathrm{R} 2$ polypeptides synthesized are not assembled with the R1 subunit to form functional receptors. This may explain the discrepancy between the relatively small increase in both $\left[{ }^{125} \mathrm{I}\right] \mathrm{MK}-801$ binding sites and the R1 polypeptide, observed after chronic antagonist exposure, and the larger increase in the $\mathrm{R} 2 \mathrm{~A} / \mathrm{B}$ polypeptides observed in the present study. Immunoprecipitation studies will be undertaken to verify this hypothesis.

The NMDAR upregulation has also been observed after chronic ethanol treatment. It should be noted that, acutely, ethanol also inhibits NMDA responses; however, the mechanism of this action has yet to be clucidated. The NMDAR binding was increased in vitro and in vivo after chronic ethanol treatment (Grant et al., 1990; Hu and Ticku, 1995). In addition, chronic ethanol exposure upregulated the NMDAR function (Hu and Ticku, 1995) and gene expression (Hu et al., 1996) of the NMDAR subunits in cultured cortical neurons. It is worth mentioning that other drugs such as ethanol, which produce upregulation of the NMDAR, like the antagonists (this study) also did not alter the mRNA levels for the R1 subunit (Follesa and Ticku, 1995; Hu et al., 1996) despite producing an apparent increase in the $\mathrm{R} 1$ polypeptide in the rat hippocampus (Trevisan et al., 1994) and an increase in the $R 1$ and $R 2$ polypeptide after chronic ethanol treatment in mouse cortical neurons (Follesa and Ticku, unpublished observations). This study provides further support to the notion that the $\mathrm{Rl}$ gene may be regulated by translational or post-transcriptional mechanisms.

In summary, our data suggest that blockade of the glutamatemediated tonic activation of the NMDAR by competitive or noncompetitive antagonists induced upregulation of the NMDAR, because of an increase in mRNA and polypeptides of the different subunits composing the NMDA oligomeric receptor complex in cortical neurons. This raises questions regarding complications that may arise if NMDAR antagonists are used as therapeutic agents to treat pathological conditions associated with excessive glutamate cascade.

\section{REFERENCES}

Aarons RD, Nies AS, Gal J, Hegstrand LR, Molinoff PB (1980) Elevation of $\beta$-adrenergic receptor density in human lymphocytes after propranolol administration. J Clin Invest 65:949-957.

Albers GW, Goldberg MP, Choi DW (1989) $N$-methyl-D-aspartate antagonists: ready for clinical trial in brain ischemia? Ann Neurol 25:398-403.

Anantharam V, Panchal RG, Wilson A, Kolchine VV, Treistman SN, Bayley H (1992) Combinatorial RNA splicing alters the surface charge on the NMDA receptor. FEBS Lett 305:27-30.

Bessho Y, Nawa M, Nakanishi S (1994) Selective up-regulation of an NMDA receptor subunit mRNA in cultured cerebellar granule cells by $\mathrm{K}^{+}$-induced depolarization and NMDA treatment. Neuron 12:87-95.

Bovolin P, Santi MR, Memo M, Costa E, Grayson DR (1992) Distinct developmental patterns of expression of rat $\alpha 1, \alpha 5, \gamma 2 \mathrm{~S}$, and $\gamma 2 \mathrm{~L}$ $\gamma$-aminobutyric acid $_{\mathrm{A}}$ receptor subunit mRNAs in vivo and in vitro. $\mathrm{J}$ Neurochem 59:62-72.

Choi DW (1988) Glutamate neurotoxicity and diseases of the nervous system. Neuron 1:623-634.

Chomczynski P, Sacchi N (1987) Single-step method of RNA isolation by acid guanidinium thiocyanate-phenol-chloroform extraction. Anal Biochem 162:156-159.

Collingridge GL, Lester RA (1989) Excitatory amino acid receptors in the vertebrate central nervous system. Pharmacol Rev 41:143-210.
Danielson PE, Forss-Petter S, Brow MA, Calavetta L, Douglass J, Milner RJ, Sutcliffe JG (1988) p1B15: a cDNA clone of the rat mRNA encoding cyclophilin. DNA 7:261-267.

Follesa P, Mocchetti I (1993) Regulation of basic fibroblast growth factor and nerve growth factor mRNA by $\beta$-adrenergic receptor activation and steroids in rat central nervous system. Mol Pharmacol 43:132-138.

Follesa P, Ticku MK (1995) Chronic ethanol treatment differentially regulates NMDA receptor subunit mRNA expression in rat brain. Mol Brain Res 29:99-106.

Godfrey EW, Nelson PG, Shrier BK, Breuer AC, Ransom BR (1975) Neurons from fetal rat brain in a new cell culture system: a multidisciplinary analysis. Brain Res 90:1-21.

Goldberg MP, Viseskul V, Choi DW (1988) Phencyclidine receptor ligands attenuate cortical neuronal injury after $N$-methyl D-aspartate exposure or hypoxia. J Pharmacol Exp Ther 245:1081-1087.

Grant KA, Valverius P, Hudspith M, Tabakof B (1990) Ethanol withdrawal seizures and the NMDA receptor complex. Eur J Pharmacol 176:289-296.

Hamilton PB (1945) Gasometric determination of glutamine amino acid carboxyl nitrogen in plasma and tissue filtrates by the ninhydrin-carbon dioxide method. J Biol Chem 158:375-395.

Hu XJ, Ticku MK (1995) Chronic ethanol treatment upregulates the NMDA receptor function and binding in mammalian cortical neurons. Mol Brain Res 30:347-356.

Hu XJ, Follesa P, Ticku MK (1996) Chronic cthanol treatment produces a selective upregulation of the NMDA receptor subunit gene expression in mammalian cultured cortical neurons. Mol Brain Res, in press.

Ishii T, Mariyoshi K, Sugihara H, Sakurada K, Kadotani H, Yokoi M, Akazawa C, Shigemoto R, Mizuno N, Masu M, Nakanishi S (1993) Molecular characterization of the family of the $N$-methyl-D-aspartate receptor subunits. J Biol Chem 268:2836-2843.

Jenner P, Marsden CD (1983) Neuroleptics and tardive dyskinesia. In: Neuroleptics: neurnchemical, behavioral and clinical perspectives (Coyle JT, Enna SJ, eds), pp 223-253. New York: Raven.

Kutsuwada T, Kashiwabuchi N, Mori H, Sakimura K, Kushiya E, Araki K, Meguro II, Masaki II, Kumanishi T, Arakawa M, Mishina M (1992) Molecular diversity of the NMDA receptor channel. Nature 358:36-41.

Laemmli UK (1970) Cleavage of structural proteins during assembly of the head of bacteriophage T4. Nature 227:680-685.

Mayer ML, Westbrook GL (1987) The physiology of excitatory amino acids in the vertebrate central nervous system. Prog Neurobiol 28:197-276.

McDonald JW, Silverstein FS, Johnston MV (1990) MK-801 pretreatment enhances $N$-methyl-D-aspartate-mediate brain injury and increases brain $N$-methyl-D-aspartate recognition site binding in rats. Neuroscience 38:103-113.

Milner RJ, Sutcliffe JG (1983) Gene expression in rat brain. Nucleic Acids Res 11:5497-5520.

Monyer H, Sprengel R, Schoepfer R, Herb A, Higuchi M, Lomeli H, Burnashev N, Sakmann B, Seeburg PH (1992) Heteromeric NMDA receptors: molecular and functional distinction of subtypes. Science 256:1217-1221.

Monyer H, Burnashev N, Lauric DJ, Sakmann B, Seeburg PH (1994) Developmental and regional expression in the rat brain and functional properties of four NMDA receptors. Neuron 12:529-540.

Moriyoshi K, Masu M, Ishii T, Shigemoto R, Mizuno N, Nakanishi S (1991) Molecular cloning and characterization of the rat NMDA receptor. Nature 354:31-37.

Muir KW, Lees KR (1995) Clinical experience with excitatory amino acid antagonist drugs. Stroke 26:503-513.

Petralia RS, Wang YX, Wenthold RJ (1994) The NMDA receptor subunits NR2A and NR2B show histological and ultrastructural localization patterns similar to those of NR1. J Neurosci 14:6102-6120.

Pujic Z, Matsumoto I, Wilce PA (1993) Expression of the gene coding for the NR1 subunit of the NMD $\Lambda$ receptor during rat brain development. Neurosci Lett 162:67-70.

Resink A, Villa M, Boer GJ, Mohler H, Balazs R (1995) Agonist-induced downregulation of NMDA receptors in cerebellar granule cells in culture. Eur J Neurosci 7:1700-1706.

Riva MA, Tascedda F, Molteni R, Racagni G (1994) Regulation of NMDA receptor subunit mRNA expression in the rat brain during postnatal development. Mol Brain Res 25:209-216. 
Sheng M, Cummings J, Roland LA, Jan YN, Jan LY (1994) Changing subunit composition of the heteromeric NMDA receptors during development of rat cortex. Nature 368:144-147.

Sucher NJ, Brose N, Deitcher DL, Awobuluyi M, Gasic GP, Bading H, Cepko CL, Greenberg ME, Jahn R, Heinemann SF, Lipton SA (1993) Expression of endogenous NMDARl transcripts without receptor protein suggests post-transcriptional control in PC12 cells. J Biol Chem 268:22299-22304.

Trevisan L, Fitzgerald LW, Brose N, Gasic GP, Heinemann SF, Duman RS, Nestler EJ (1994) Chronic ingestion of ethanol up-regulates NMDAR1 receptor subunit immunoreactivity in rat hippocampus. J Neurochem 62:1635-1638.

Veres G, Gibbs RA, Scherer SE, Caskey CT (1987) The molecular basis of the sparse fur mouse mutation. Science 237:415-417.

Watanabe M, Mishina M, Inoue Y (1994) Distinct gene expression of the $N$-methyl-D-aspartate receptor channel subunit in peripheral neurons of the mouse sensory ganglia and adrenal gland. Neurosci Lett 165:183-186.

Watkins JC, Krogsgaard-Larsen P, Honore T (1990) Structure-activity relationship in the development of excitatory amino acid receptor agonist and competitive antagonists. Trends Pharmacol Sci 11:25-33.

Wenthold RJ, Trumpy VA, Zhu W, Petralia RS (1994) Biochemical and assembly properties of GluR6 and KA2, two members of the kainate receptor family, determined with subunit-specific antibodies. J Biol Chem 269:1332-1339.

Williams K, Dichter MA, Molinoff PB (1992) Up-regulation of $N$-methyl-D-aspartate receptors on cultured cortical neurons after exposure to antagonists. Mol Pharmacol 42:147-151.

Zhong J, Russel SL, Pritchett DB, Molinotf PB, Williams K (1994) Expression of mRNAs encoding subunits of the $N$-methyl-D-aspartate receptor in cultured cortical neurons. Mol Pharmacol 45:846-853. 